\title{
CONTROLLING FACTORS OF NITROUS OXIDE EMISSIONS FROM A CONVENTIONAL ACTIVATED SLUDGE WASTEWATER TREATMENT PLANT
}

\author{
Renato P. Ribeiro ${ }^{1}$ \\ Renata B. Alvim ${ }^{1}$ \\ Samara A. Andrade ${ }^{1}$ \\ Débora C. Kligerman ${ }^{2}$ \\ Paulo A. de Almeida ${ }^{3}$ \\ Jaime L. M. Oliveira ${ }^{2}$ \\ William Z. de Mello ${ }^{1}$
}

\begin{abstract}
Nitrous oxide emissions were determined in three campaigns in the aeration tank of a full scale conventional activated sludge wastewater treatment plant. During these experiments, the carbonaceous organic matter (BOD and COD) removal was high and rather constant (97-98\% and 93-96\%). The results indicate that the concentration of total nitrogen in the influent wastewater, especially $\mathrm{NH}_{4}{ }^{+}$, and the aeration flow rate are key controlling factor of $\mathrm{N}_{2} \mathrm{O}$ emissions from the aeration tank. Nitrification was the major source of $\mathrm{N}_{2} \mathrm{O}$, suggested by the behavior of DO concentrations, $\mathrm{NO}_{3}{ }^{-} / \mathrm{NH}_{4}{ }^{+}$ratio and $\mathrm{pH}$ values along the six interlinked zones of the aeration tank. Excessive air flow intensified $\mathrm{N}_{2} \mathrm{O}$ transfer from the liquor to the atmosphere by air stripping.
\end{abstract}

Keywords: nitrous oxide, wastewater treatment plant, activated sludge.

\footnotetext{
${ }^{1}$ Departamento de Geoquímica, Instituto de Química, Universidade Federal Fluminense. E-mail: renato.quimica@yahoo.com.br; renatabalvim@gmail.com; samaraandrade@id.uff.br; zamboni@geoq.uff.br ${ }^{2}$ Departamento de Saneamento e Saúde Ambiental, Escola Nacional de Saúde Pública, Fundação Oswaldo Cruz.E-mail: kliger@ensp.fiocruz.br; jaimel@ensp.fiocruz.br

${ }^{3}$ Companhia Estadual de Águas e Esgotos, CEDAE. E-mail: paulo-almeida@cedae.com.br
} 


\section{INTRODUCTION}

Tropospheric nitrous oxide $\left(\mathrm{N}_{2} \mathrm{O}\right)$ is the third gas, in concentration, responsible for the greenhouse effect, and its contribution to radiative forcing was about $+0.16 \mathrm{~W} \mathrm{~m}^{-2}$ in the period from 1750 to 2005 (6\% of the total contribution) (IPCC, 2007). Nitrous oxide is the first gas in relation to global warming potentials with values in the order of 300 and 15 times higher than carbon dioxide $\left(\mathrm{CO}_{2}\right)$ and methane $\left(\mathrm{CH}_{4}\right)$, respectively (IPCC, 2007). Moreover, $\mathrm{N}_{2} \mathrm{O}$ is the major source of nitric oxide (NO) in the stratosphere which implies that it is indirectly responsible for the consumption of stratospheric ozone $\left(\mathrm{O}_{3}\right)$ (Crutzen, 1979; Abbat and Molina, 1993; Ravishankara et al., 2009).

In wastewater treatment plants (WWTPs), $\mathrm{N}_{2} \mathrm{O}$ emissions occur naturally due to the microbial transformations of nitrogen compounds by the nitrification and denitrification processes (Wrage et al., 2001). Under aerobic conditions, $\mathrm{N}_{2} \mathrm{O}$ production occurs, as a by-product, through oxidation of ammonium ions $\left(\mathrm{NH}_{4}{ }^{+}\right)$to nitrite $\left(\mathrm{NO}_{2}{ }^{-}\right)$, the first stage of the nitrification process. Conversely, in anoxic compartments, $\mathrm{N}_{2} \mathrm{O}$ production occurs as an intermediate during reduction of nitrate $\left(\mathrm{NO}_{3}{ }^{-}\right)$to molecular nitrogen $\left(\mathrm{N}_{2}\right)$, i.e., via denitrification. In addition, $\mathrm{N}_{2} \mathrm{O}$ produced by denitrification may subsequently come under aerated conditions and is then purged from the system (Czepiel et al., 1995; Ahn et al., 2010; Law et al., 2012a).

It is estimated that there will be an increase of $13 \%$ in global $\mathrm{N}_{2} \mathrm{O}$ emissions from wastewater treatment for the 20052020 period (Law et al., 2012a). However, there is a high variability in emission factors (EFs) (0-25\%), based on the load of the influent total nitrogen $(\mathrm{TN})$, available in the literature from studies performed directly at WWTPs (Kampschreur et al., 2009; Law et al., 2012a). This variability is often attributed to the particularities related to operational parameters adopted at the different WWTPs studied, highlighting among them, the organic matter and $\mathrm{TN}$ to be treated, sludge age, dissolved oxygen (DO) concentration and aeration rate (Kampschreur et al., 2009; Brotto et al., 2010; Brotto, 2011; Law et al., 2012a; de Mello et al., 2013; Ribeiro et al., 2013). Recently, Daelman et al. (2013) reported that different sampling strategies used at the WWTPs studied can also play an important role as an influencing factor in the observed variability in EFs of $\mathrm{N}_{2} \mathrm{O}$.

In a study performed at an activated sludge WWTP in Brazil, Brotto et al. (2010) reported that $90 \%$ of the total $\mathrm{N}_{2} \mathrm{O}$ emitted originated from the aeration tank. De Mello et al. (2013) estimated, through a study at an intermittent aeration activated sludge system of an urban WWTP, with cycles of 60 minutes with aeration and 30 minutes without aeration, that $50-75 \%$ of the net production of $\mathrm{N}_{2} \mathrm{O}$ was emitted to the atmosphere during the aeration step (aerobic condition). Foley et al. (2010) and Ribeiro et al. (2013) suggested that lower $\mathrm{N}_{2} \mathrm{O}$ emissions are related to the higher removal efficiency of $\mathrm{TN}$ when there is complete nitrification and denitrification processes. In a study performed at an activated sludge WWTP with modified aeration, Brotto (2011) found that the sludge age influenced the nitrification process. Also the high $\mathrm{N}_{2} \mathrm{O}$ emissions were due to accumulation of $\mathrm{NO}_{2}{ }^{-}$in the aeration tank, which indicated incomplete nitrification. These studies highlight the importance of controlling the operating parameters in order to minimize $\mathrm{N}_{2} \mathrm{O}$ emissions.

The present study aims to evaluate the relationship of $\mathrm{N}_{2} \mathrm{O}$ emissions with the influent TN load, DO concentration, ratio of inorganic nitrogen forms $\left(\mathrm{NO}_{3}{ }^{-}\right.$ $\left./ \mathrm{NH}_{4}{ }^{+}\right)$, pH and flow rates of air and wastewater $\left(\mathrm{Q}_{\text {air }} / \mathrm{Q}_{\text {wastewater }}\right)$ in an aeration tank of a conventional activated sludge WWTP, aiming to find solutions to mitigate $\mathrm{N}_{2} \mathrm{O}$ emissions in this type of system. 


\section{EXPERIMENTAL}

\subsection{Location and Characteristics of the WWTP}

The WWTP chosen for this study, the same one studied by Ribeiro et al. (2013) is located in the metropolitan region of Rio de Janeiro, Southeast Brazil. It is considered a large-scale WWTP and uses a conventional activated sludge system as the wastewater treatment process. During the study period, the plant served approximately 470,000 residents and operated with a hydraulic retention time (HRT) of about 9 hours in the aeration tank and the sludge age varied from 10 to 12 days.

The WWTP has three levels of wastewater treatment: the primary, secondary and sludge treatment. In the secondary treatment, the WWTP has four aeration tanks in operation that are adjacent and independent to each other, but with the same operating characteristics. Each of the four aeration tanks is divided into six interlinked aeration zones (ZNs). The zones have different air flow rates controlled according to the number of diffusers in each of them $(\mathrm{ZN} 1=29, \mathrm{ZN} 2=1184$, $\mathrm{ZN} 3=640, \mathrm{ZN} 4=500, \mathrm{ZN} 5=898$, and ZN6 = 612) (Ribeiro et al., 2013).

The $\mathrm{ZN1}$ is differentiated from the other zones by the presence of coarse bubble diffusers applied to mix the effluent from the primary treatment with the biological sludge that returns from the secondary settling (Ribeiro et al., 2013). Furthermore, due to the low HRT, high food/microorganism (F/M) ratio and low DO concentration $\left(\leq 0.5 \mathrm{mg} \mathrm{L} \mathrm{L}^{-1}\right)$ employed in the $\mathrm{ZN1}$ compared to the other zones, this zone can be characterized as a biological anoxic selector, which is a system that promotes a better formation of sludge flocs (von Sperling, 2002). The other zones (ZN2 to ZN6) are characterized by having fine bubble diffusers (Ribeiro et al., 2013), whose function is to promote a good mixing capacity and raise the oxygen supply in the liquid (von Sperling, 2002), which characterizes aerobic conditions in these zones, with sufficient sludge age and HRT for complete nitrification processes.

\subsection{Sampling and Analysis}

For this study, three sampling campaigns were carried out, on May 18, 2010, and February 17 and June 30, 2011. The study was conducted in only one of the four aeration tanks. This choice was based on the similarity of the aeration tank operations, since the wastewater and air flows are distributed equally in the four aeration tanks that make up the secondary treatment system. The samples were collected only in the morning, between 8:00 and 11:00 h. The sampling took place at 24 equidistant sites distributed along the margins of the six zones of the aeration tank (i.e., four sampling sites per zone) following the direction of the course of the mixed liquor.

During the sampling campaigns, DO concentration and $\mathrm{pH}$ were measured in situ using a multiparameter probe HI9828 model (Hanna Instruments). In addition, influent (untreated wastewater) and effluent (treated wastewater) samples were collected for the determination of $\mathrm{TN}$ concentrations in the laboratory. Data of biochemical oxygen demand (BOD) and chemical oxygen demand (COD) in influent and effluent samples, and volatile suspended solids (VSS) in each of the six zones of the aeration tank, were provided by the control laboratory of the WWTP.

The procedures for collecting, processing and analyzing $\mathrm{N}_{2} \mathrm{O}, \mathrm{NH}_{4}{ }^{+}$and $\mathrm{NO}_{3}{ }^{-}$in the wastewater and the mixed liquor samples, and for calculating the $\mathrm{N}_{2} \mathrm{O}$ emissions were the same as those described by Ribeiro et al. (2013). To determine the $\mathrm{N}_{2} \mathrm{O}$ emission at the wastewater-atmosphere interface of each zone of the aeration tank the upturned funnel sampling technique, described in detail by Brotto et al. (2010) was used. This same technique was adopted by Ribeiro et al. (2013).

In the laboratory, the determination of $\mathrm{N}_{2} \mathrm{O}$ was performed in a gas chromatography (GC-17/Shimadzu) 
equipped with an electron capture detector $\left({ }^{63} \mathrm{Ni}\right)$. The limits of detection and quantification were 30 and $300 \mathrm{ppb}$, respectively. The quantification limit of the $\mathrm{N}_{2} \mathrm{O}$ emission rate using the upturned funnel technique was $4 \times 10^{-3} \mathrm{~g} \mathrm{~N}_{2} \mathrm{O} \mathrm{h}^{-1}$. The concentrations of $\mathrm{NH}_{4}{ }^{+}$and $\mathrm{NO}_{3}{ }^{-}$ were determined on filtered samples $(0.22 \mu \mathrm{m}$ pore size filters) and stored in a freezer $\left(-4^{\circ} \mathrm{C}\right)$. The $\mathrm{TN}$ was determined in unfiltered and acidified ( $\mathrm{pH}$ 2.0) samples. All analyzes followed the procedures according to APHA (2012). The limit of quantification was $0.2 \mathrm{mg} \mathrm{L}^{-1}$ for $\mathrm{NH}_{4}^{+}$ and $\mathrm{NO}_{3}{ }^{-}$, and $10 \mathrm{mg} \mathrm{N} \mathrm{L}{ }^{-1}$ for TN. The analytical precisions, for analysis performed in triplicate, of $\mathrm{NH}_{4}{ }^{+}, \mathrm{NO}_{3}{ }^{-}$ and $\mathrm{TN}$ were within $\pm 5 \%$.

\section{RESULTS AND DISCUSSION}

The parameters controlling $\mathrm{N}_{2} \mathrm{O}$ emissions from activated sludge wastewater treatment systems, which are widely discussed in the literature, derive mainly from laboratory studies (Kim et al., 2010; Rassamee et al., 2011; Law et al., 2012b; Wunderlin et al., 2012). In this work, the key controlling factors are presented and discussed based on data obtained exclusively from the abovedescribed full scale wastewater treatment system.

\subsection{Influent BOD, COD and $\mathrm{NH}_{4}{ }^{+}$ concentrations}

Figure 1 shows the temporal variability in the concentrations of BOD and COD in the influent wastewater of the WWTP for the period JanuaryDecember 2010. The arithmetic mean concentration ( \pm standard deviation) of COD was $600( \pm 260) \mathrm{mg} \mathrm{L}^{-1}(\mathrm{n}=12)$, approximately 2 times higher than the mean BOD concentration. In the summer months lower concentrations were observed probably as a result of increased dilution due to greater domestic water consumption and a greater input of rainwater in the wastewater collection networks (von Sperling, 2002; Ribeiro et al., 2013). During the period from January to June 2010, Ribeiro et al. (2013) observed that the $\mathrm{TN}$ concentrations, especially $\mathrm{NH}_{4}^{+}$, had similar behaviour patterns to the BOD and COD concentrations. They also reported lower emissions of $\mathrm{N}_{2} \mathrm{O}$ in the summer months and attributed these to the lower concentrations of $\mathrm{NH}_{4}{ }^{+}$in the influent wastewater at that time of the year. The temporal variability of $\mathrm{N}_{2} \mathrm{O}$ emissions in activated sludge wastewater treatment systems has been frequently reported in the literature as directly related to the concentration of $\mathrm{NH}_{4}^{+}$in the influent wastewater (Ahn et al., 2010; Lotito et al., 2012; Aboobakar et al., 2013; Hu et al., 2013).

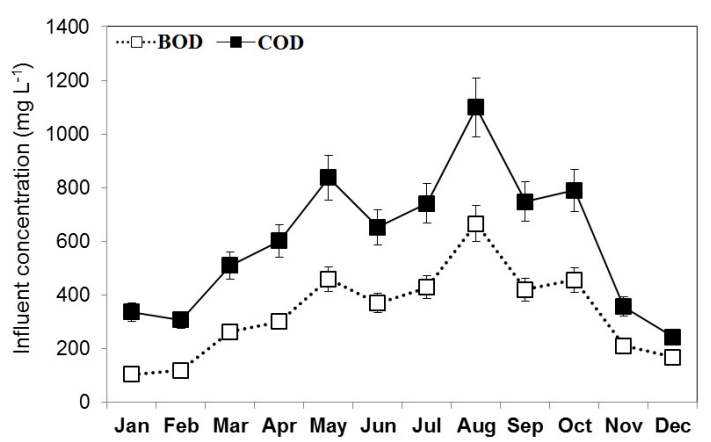

Figure 1. Temporal variability of BOD and COD concentrations (average \pm standard deviation) in wastewater influent to the WWTP, measured from January to December 2010

Table 1 shows the influent (untreated wastewater) loads of BOD, COD and TN to the WWTP, the influent (primary wastewater) $\mathrm{NH}_{4}{ }^{+}$load to the aeration tank and the rate of $\mathrm{N}_{2} \mathrm{O}$ emission from the aeration tank on the sampling days. It is noteworthy that on the February 17 and June 30, 2011, the air flow in the aeration tank was approximately 2 times greater than May 18, 2010 (Table 2). 
Table 1. Influent (untreated wastewater) loads of BOD, COD and TN to the WWTP, influent (primary wastewater) $\mathrm{NH}_{4}{ }^{+}$load to the aeration tank, and $\mathrm{N}_{2} \mathrm{O}$ emissions from the aeration tank during the study days

\begin{tabular}{|l|c|c|c|c|c|}
\hline \multicolumn{1}{|c|}{ Sampling date } & $\begin{array}{c}\text { BOD } \\
\left(\mathrm{kg} \mathrm{day}^{-1}\right)\end{array}$ & $\begin{array}{c}\mathrm{COD} \\
\left(\mathrm{kg} \mathrm{day}^{-1}\right)\end{array}$ & $\begin{array}{c}\mathrm{TN} \\
\left(\mathrm{kg} \mathrm{day}^{-1}\right)\end{array}$ & $\begin{array}{c}\mathrm{N}^{-\mathrm{NH}_{4}}{ }^{+} \\
\left(\mathrm{kg} \mathrm{day}^{-1}\right)\end{array}$ & $\begin{array}{c}\mathrm{N}^{-} \mathrm{N}_{2} \mathrm{O} \text { emitted } \\
\left(\mathrm{kg} \mathrm{day}^{-1}\right)\end{array}$ \\
\hline May 18, 2010 & $6.2 \times 10^{4}$ & $1.1 \times 10^{5}$ & $7.5 \times 10^{3}$ & $1.1 \times 10^{3}$ & 2.4 \\
\hline February 17, 2011 & $3.2 \times 10^{4}$ & $7.4 \times 10^{4}$ & $4.4 \times 10^{3}$ & $5.5 \times 10^{2}$ & 2.9 \\
\hline June 30, 2011 & $4.2 \times 10^{4}$ & $8.7 \times 10^{4}$ & $5.4 \times 10^{3}$ & $7.7 \times 10^{2}$ & 4.1 \\
\hline
\end{tabular}

In June 30, 2010, the influent loads of BOD, $\mathrm{COD}, \mathrm{TN}$ and $\mathrm{NH}_{4}{ }^{+}$were respectively $25 \%, 15 \%, 20 \%$ and $30 \%$ higher than those in February 17, 2011, which may explain the higher $\mathrm{N}_{2} \mathrm{O}$ emission rate (ca. 30\%) in June 30 (Table 2). These results suggest that the concentration of $\mathrm{TN}$ in the influent wastewater, especially $\mathrm{NH}_{4}{ }^{+}$, is a key controlling factor of $\mathrm{N}_{2} \mathrm{O}$ emissions in the activated sludge wastewater treatment systems. This relationship is in agreement to that reported by Ribeiro et al. (2013) in a previous study at the same WWTP. In May 18, 2010, despite the organic load was almost $50 \%$ higher, the $\mathrm{N}_{2} \mathrm{O}$ emission rate was $70 \%$ lower than that found in June 30, 2011, which is attributed due to the lower aeration rate (air stripping) in May 18, 2010 (Table 2).

Table 2. Air flow rates per aeration tank, ratios between of air flow and wastewater flow $\left(\mathrm{Q}_{\text {air }} / \mathrm{Q}_{\text {wastewater }}\right)$, and $\mathrm{BOD}, \mathrm{COD}$ and $\mathrm{TN}$ removal efficiencies during the study days

\begin{tabular}{|l|c|c|c|c|}
\hline \multicolumn{1}{|c|}{ Sampling date } & $\begin{array}{c}\text { Air flow } \\
\left(\mathrm{m}^{3} \mathrm{~h}^{-1}\right)\end{array}$ & $\left(\mathrm{Q}_{\text {air }} / \mathrm{Q}_{\text {wastewater }}\right)$ & $\begin{array}{c}\text { BOD removal } \\
\text { efficiency (\%) }\end{array}$ & $\begin{array}{c}\text { COD removal } \\
\text { efficiency (\%) }\end{array}$ \\
\hline May 18, 2010 & 5000 & 3.6 & 98 & 96 \\
\hline February 17, 2011 & 9500 & 6.3 & 98 & 93 \\
\hline June 30, 2011 & 9500 & 6.7 & 97 & 96 \\
\hline
\end{tabular}

\subsection{Concentration of $\mathrm{DO}$, ratio $\mathrm{NO}_{3}{ }^{-}$ $/ \mathrm{NH}_{4}{ }^{+}$and $\mathrm{pH}$ in the aeration tank}

Figure 2a shows the patterns of $\mathrm{N}_{2} \mathrm{O}$ emissions and concentrations of $\mathrm{NH}_{4}{ }^{+}, \mathrm{NO}_{3}{ }^{-}$and $\mathrm{DO}$ along the six zones of the aeration tank for the sampling carried out on May 18, 2010. The $\mathrm{NH}_{4}^{+}$ concentration decreased from $\mathrm{ZN} 1$ to ZN6, whereas $\mathrm{N}_{2} \mathrm{O}$ emission increased, culminating in ZN5. Higher $\mathrm{N}_{2} \mathrm{O}$ production, due to nitrification mainly, and emission were expected in $\mathrm{ZN} 2$ due to both the elevated concentration of $\mathrm{NH}_{4}{ }^{+}$in the prior zone (ZN1) $\left(7.8 \mathrm{mg} \mathrm{L}^{-}\right.$ $\left.{ }^{1}\right)$ and the greatest number of diffusers in ZN2 (1184) compared to other zones. However, observing Figure 2a, it is noticeable that the oxidation of $\mathrm{NH}_{4}{ }^{+}$is much faster in the segment ZN4-ZN6 than that in ZN1-ZN4. In the intersection zone (ZN4), DO concentration and $\mathrm{N}_{2} \mathrm{O}$ emission begin to rise. It follows that the rates of $\mathrm{NH}_{4}{ }^{+}$oxidation and concomitant
$\mathrm{N}_{2} \mathrm{O}$ production raise sharply in the segment ZN4-ZN6. So, the most plausible hypothesis to explain the pattern of DO and $\mathrm{N}$ compounds shown in Figure $2 \mathrm{a}$ is that with decreasing concentration of organic matter along the zones, the DO concentration increases, thereby favoring nitrification and $\mathrm{N}_{2} \mathrm{O}$ production ( $\mathrm{DO} \geq 2 \mathrm{mg} \mathrm{L}^{-1}$ ) (Surampalli et al., 1997; Ribeiro et al., 2013). Additionally, the greater number of diffusers in ZN5 (898) as compared to $\mathrm{ZN} 4$ (500) and ZN6 (612) also contributes to the high $\mathrm{N}_{2} \mathrm{O}$ emission rate at $\mathrm{ZN} 5$ due to air stripping.

Figure $2 b$ shows the evolution of the nitrification process through the pattern of the $\mathrm{NO}_{3}{ }^{-} / \mathrm{NH}_{4}{ }^{+}$ratio and $\mathrm{pH}$ throughout the six zones of the aeration tank in the sampling carried out on May 18, 2010. The low values of $\mathrm{NO}_{3}{ }^{-} / \mathrm{NH}_{4}{ }^{+}$ between $\mathrm{ZN} 1$ and $\mathrm{ZN} 4$ indicate that complete nitrification was not occurring throughout this segment. The gradual 
drop in $\mathrm{pH}$ from $\mathrm{ZN} 1$ to $\mathrm{ZN} 4$ can be attributed to the oxidation of organic matter. The sharp increase in $\mathrm{NO}_{3}{ }^{-} / \mathrm{NH}_{4}{ }^{+}$ and sudden reduction in $\mathrm{pH}$ from $\mathrm{ZN} 4$ to ZN6 suggests the occurrence of nitrification (partial or complete) in these zones of the aeration tank. The oxidation of $\mathrm{NH}_{4}^{+}$to $\mathrm{NO}_{2}^{-}$, the first step of the nitrification process, releases two $\mathrm{H}^{+}$per mol of $\mathrm{NH}_{4}{ }^{+}$oxidized. Subsequently, $\mathrm{NO}_{2}{ }^{-}$is rapidly oxidized to $\mathrm{NO}_{3}{ }^{-}$(second nitrification step) with no release of $\mathrm{H}^{+}$. This is clearly shown by the $\mathrm{NO}_{3}{ }^{-} / \mathrm{NH}_{4}{ }^{+}$ ratio and $\mathrm{pH}$ in the last zones of the aeration tank (Figure 2a).

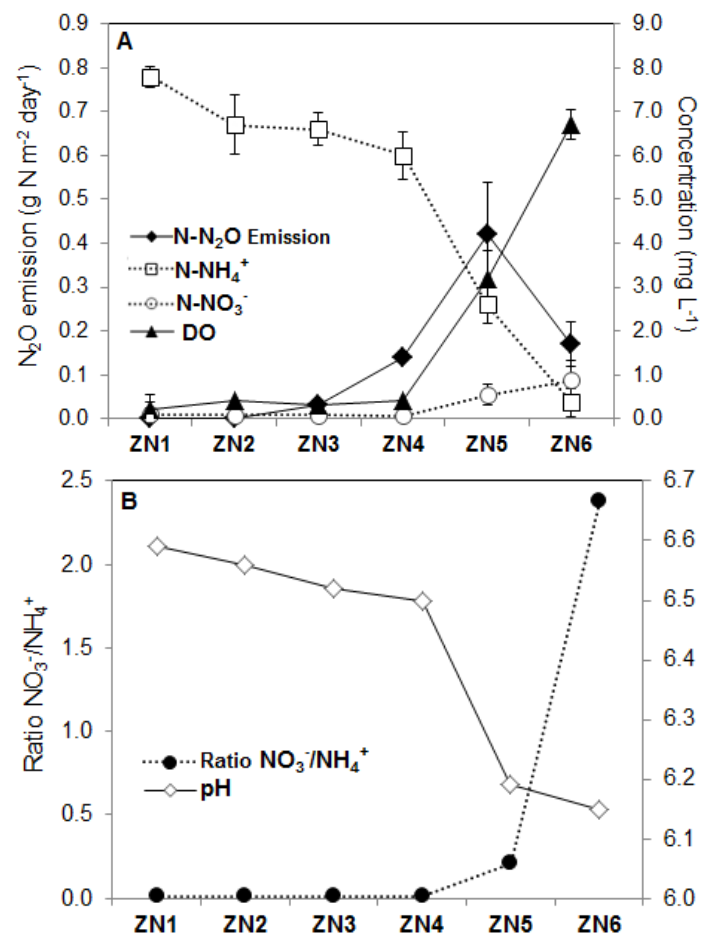

Figure 2. (a) Spatial variability of $\mathrm{N}_{2} \mathrm{O}$ emissions and $\mathrm{N}-\mathrm{NH}_{4}{ }^{+}, \mathrm{N}-\mathrm{NO}_{3}{ }^{-}$and $\mathrm{DO}$ concentrations (average \pm standard deviation) along the six zones of the aeration tank on May 18, 2010. (b) Spatial variability of $\mathrm{N}-\mathrm{NO}_{3}{ }^{-} / \mathrm{N}-\mathrm{NH}_{4}{ }^{+}$ (molar) ratio and $\mathrm{pH}$ along the six zones of the aeration tank on May 18, 2010.

The Figures $3 \mathrm{a}$ and $3 \mathrm{~b}$ show the results of the sampling carried out on February 17 and June 30, 2011, respectively. On both sampling days, the aeration tank was operated with an influent air flow rate of about 2 times higher than that used on May 18, 2010 (Table 2). Figure 3a (February 17, 2011) shows a different pattern from that observed in Figure 2a (May 18, 2010), with the largest $\mathrm{N}_{2} \mathrm{O}$ emission occurring in ZN2. This outcome may be linked to a more rapid oxidation of $\mathrm{NH}_{4}^{+}$under conditions of higher aeration rate and lower influent organic load (BOD and COD) to the WWTP (Table 1). This condition favors greater availability of DO (DO $\geq 2 \mathrm{mg} \mathrm{L}^{-1}$ ) for the oxidation of the organic matter and for the complete nitrification in the initial zones of the aeration tank.

Interestingly, Figure 3b (June 30, 2011) shows a very similar pattern of DO and $\mathrm{N}$ compounds to that observed in Figura 2a (May 18, 2010), with higher $\mathrm{N}_{2} \mathrm{O}$ emission in $\mathrm{ZN} 5$, probably due to ca. 30\% higher organic loading rate and equivalent aeration rate compared to that on February 17, 2011. These conditions seems to favor the heterotrophic metabolism and the nitrification process in the initial zones of the aeration tank. Similarly as observed on May 18, 2010, the nitrification process on February 17, 2011, intensified in the segment ZN4ZN5.

Figures $3 \mathrm{c}$ and $3 \mathrm{~d}$ show the evolution of $\mathrm{NO}_{3}{ }^{-} / \mathrm{NH}_{4}{ }^{+}$ratio and $\mathrm{pH}$ throughout the six aeration zones on February 17 and June 30, 2011, respectively. There is a clear opposite pattern between $\mathrm{NO}_{3}{ }^{-} / \mathrm{NH}_{4}{ }^{+}$ratio and $\mathrm{pH}$, supporting the effect of oxidation of organic matter and nitrification on $\mathrm{pH}$. The $\mathrm{NO}_{3}{ }^{-} / \mathrm{NH}_{4}{ }^{+}$ratio and $\mathrm{pH}$ patterns were strikingly similar during both the May 18, 2010, and June 30, 2011, campaigns. Nevertheless, the $\mathrm{NO}_{3}{ }^{-} / \mathrm{NH}_{4}{ }^{+}$ values in $\mathrm{ZN} 5-\mathrm{ZN} 6$ were about 1 order of magnitude higher on June 30, 2011, (Figures $2 \mathrm{~b}$ and $3 \mathrm{~d}$ ) due to the higher influent air flow rate during this campaign (Table 1). This outcome reinforces the hypothesis that with a high influent organic load, DO is restricted to degradation of organic matter and is used by nitrifying organisms only when there is a decrease in organic load along the zones. 


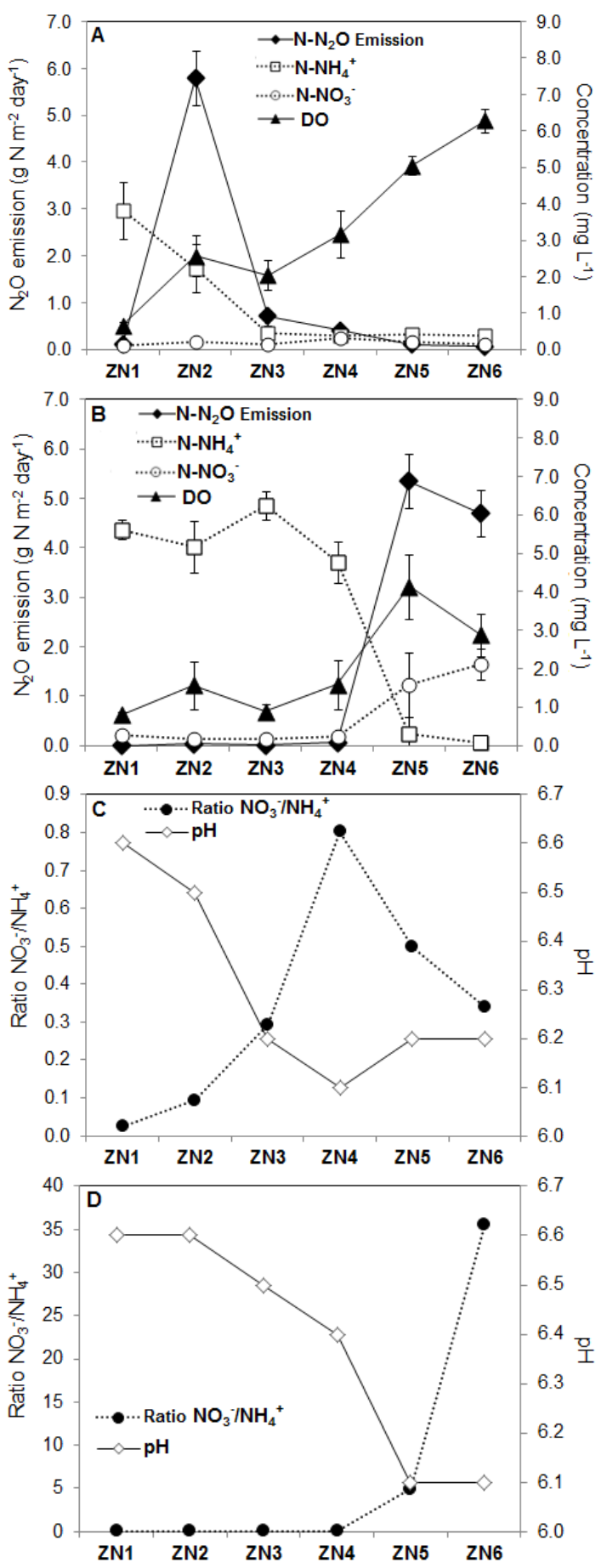

Figure 3. Spatial variability of $\mathrm{N}_{2} \mathrm{O}$ emissions and $\mathrm{N}-\mathrm{NH}_{4}{ }^{+}, \mathrm{N}-\mathrm{NO}_{3}{ }^{-}$and DO concentrations (average \pm standard deviation) along the six zones of the aeration tank on February 17, 2011 (a), and on June 30, 2011 (b). Spatial variability of $\mathrm{N}_{-} \mathrm{NO}_{3}{ }^{-} / \mathrm{N}-\mathrm{NH}_{4}{ }^{+}$(molar) ratios and $\mathrm{pH}$ along the six zones of the aeration tank on February 17, 2011 (c), and on June 30, 2011 (d).

\subsection{Ratio $Q_{\text {air }} / \mathbf{Q}_{\text {wastewater in the }}$ aeration tank}

Figures 2 and 3 show that the $\mathrm{N}_{2} \mathrm{O}$ production is dependent on $\mathrm{DO}$ and $\mathrm{NH}_{4}{ }^{+}$ concentrations. Also, its emission is directly proportional to the aeration rate of wastewater. The average $\mathrm{N}_{2} \mathrm{O}$ emissions observed during the two 2011 campaigns (Figures $3 a$ and $3 b$ ) were an order of magnitude higher than that in 2010 (Figure 2a), independently of the influent organic load. This is due to the fact that in 2011, the influent air flow rate in the aeration tank was 2 times higher than that used in 2010 (Table 2), which strongly support the hypotesis that the aeration rate influences the $\mathrm{N}_{2} \mathrm{O}$ emission rate, due to enhancement of both the nitrification rate and the removal of supersaturated $\mathrm{N}_{2} \mathrm{O}$ in the liquid by air stripping, as has already been mentioned by other authors (Czepiel et al., 1995; Ahn et al., 2010; Brotto et al., 2010; Aboobakar et al., 2013; de Mello et al., 2013).

Table 3. Emission factors based on the population served, flow of untreated wastewater and influent TN load during the study days

\begin{tabular}{|c|c|c|c|}
\hline \multirow[t]{2}{*}{ Sampling date } & \multicolumn{3}{|c|}{ Emission factors } \\
\hline & $\left(\mathrm{g} \mathrm{N}_{2} \mathrm{O}\right.$ person $^{-1}$ year $\left.^{-1}\right)$ & $\left(\mathrm{g} \mathrm{N}_{2} \mathrm{O} \mathrm{L}^{-1}\right.$ wastewater $)$ & $\begin{array}{l}\left(\% \mathrm{~N}_{2} \mathrm{O}-\mathrm{N} \text { emitted per }\right. \\
\text { influent TN load) }\end{array}$ \\
\hline May 18, 2010 & 3.0 & $3.0 \times 10^{-5}$ & 0.04 \\
\hline February 17,2011 & 13.8 & $1.2 \times 10^{-4}$ & 0.26 \\
\hline June 30,2011 & 19.6 & $1.9 \times 10^{-4}$ & 0.30 \\
\hline
\end{tabular}

The ratio of air flow rate $\left(\mathrm{Q}_{\text {air }}\right)$ to wastewater flow rate $\left(\mathrm{Q}_{\text {wastewater }}\right)$ per tank for May 18, 2010, was almost two times lower than those for February 17 and
June 30, 2011 (Table 2). The $\mathrm{N}_{2} \mathrm{O}$ emission factors (EFs) for the two studies carried out in 2011, based on the population served, flow of untreated 
wastewater and influent TN load, were almost one order of magnitude greater than that observed in 2010 (Table 3). Furthermore, the two 2011 EFs were higher than the EF (3.2 (2-8) $\mathrm{g} \mathrm{N}_{2} \mathrm{O}$ person $^{-1}$ year $^{-1}$ ) proposed by the IPCC guidelines (2006).

The main controlling factors of $\mathrm{N}_{2} \mathrm{O}$ emissions in the activated sludge WWTPs are the concentration of influent $\mathrm{TN}$, the sludge age, the DO concentration and aeration rate (Brotto et al., 2010; Brotto, 2011; Lotito et al., 2012; Aboobakar et al., 2013; de Mello et al., 2013; Hu et al., 2013; Ribeiro et al., 2013). Foley et al. (2010) and Ribeiro et al. (2013) highlighted the importance of precise control in operational parameters regarding to the $\mathrm{N}_{2} \mathrm{O}$ production and emission in aeration tanks from activated sludge WWTPs, which is strongly linked with the removal efficiency of TN.
This study shows that besides other factors, the aeration rate has a strong relationship to $\mathrm{N}_{2} \mathrm{O}$ emissions because it determines control of DO concentration and physically affects the transfer process of the supersaturated fraction of $\mathrm{N}_{2} \mathrm{O}$ from the liquid phase to the atmosphere (Tables 2 and 3). De Mello et al. (2013) showed the importance of this operating parameter in controlling $\mathrm{N}_{2} \mathrm{O}$ emission of an aeration tank operated with an intermittent aeration system. Table 4 shows the EFs from previous studies carried out in four WWTPs in Rio de Janeiro with distinct values of sludge age and $\mathrm{Q}_{\text {air }} / \mathrm{Q}_{\text {wastewater }}$ ratio. Among those four studies, the one with intermediate sludge age and lowest $\mathrm{Q}_{\text {air }} / \mathrm{Q}_{\text {wastewater }}$ ratio revealed the lowest $\mathrm{N}_{2} \mathrm{O}$ EF. Accordingly, if the aim is to lessen $\mathrm{N}_{2} \mathrm{O}$ emissions from activated sludge WWTPs, it is important to control the key operating parameters.

Table 4. Emission factors of $\mathrm{N}_{2} \mathrm{O}$, based on the population served, for studies carried out in WWTPs, located in Southeast Brazil, with activated sludge systems exhibiting diverse operational characteristics

\begin{tabular}{|c|c|c|c|c|}
\hline References & $\begin{array}{l}\text { Aeration } \\
\text { system } \\
\text { employed }\end{array}$ & $\begin{array}{l}\text { Sludge } \\
\text { age } \\
\text { (days) }\end{array}$ & $\left(\mathrm{Q}_{\text {air }} / \mathrm{Q}_{\text {wastewater }}\right)$ & 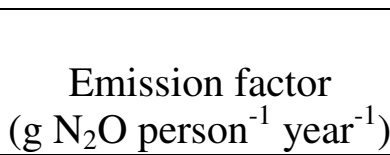 \\
\hline Brotto et al.(2010) & Extended & 25 & 11.5 & 13 \\
\hline Brotto (2011) & Modified & 3 & 8.8 & 8.1 \\
\hline de Mello et al. (2013) & Intermittent & 13 & 25.6 & 8.8 \\
\hline Ribeiro et al. (2013) & Conventional & $10-12$ & 3.3 & 1.3 \\
\hline
\end{tabular}

The use of $\mathrm{N}_{2} \mathrm{O}$ emission as an operational parameter to control the rate of aeration in the activated sludge WWTPs has already been proposed and discussed in the literature by different authors (Burgess et al., 2002; Sivret et al., 2008; Butler et al., 2009). The findings shown in this study reinforce the viability of using systematic measurements of $\mathrm{N}_{2} \mathrm{O}$ emissions in aeration tanks of activated sludge WWTPs as an indicator of the aeration rate necessary to promote microbiological processes for the oxidation of organic matter and nitrogen removal.

\section{CONCLUSIONS}

Three in situ experiments, conducted in an activated sludge WWTP, strengthen the influence of the total $\mathrm{N}$ loading rate, especially ammonium, and the aeration flow rate on the emission rate of $\mathrm{N}_{2} \mathrm{O}$ from the aeration tank. The variation of $\mathrm{NH}_{4}{ }^{+}, \mathrm{NO}_{3}{ }^{-}$and $\mathrm{DO}$ concentrations and $\mathrm{pH}$ values along the six interlinked aeration zones strongly suggested that $\mathrm{N}_{2} \mathrm{O}$ formation occurred mainly through nitrification. During these experiments, the carbonaceous organic matter removal was high and rather constant (93-96\%). Excessive air flow intensifies $\mathrm{N}_{2} \mathrm{O}$ transfer from liquor to the atmosphere by air stripping, wastes energy and increases plant-operating costs. 


\section{REFERENCES}

ABBAT, J. P. D.; MOLINA, M. J. 1993. Status of stratospheric ozone depletion. Annual Review of Environment and Resources, 18, 1-29.

ABOOBAKAR, A.; CARTMELL, E.; STEPHENSON, T; JONES, M.; VALE, P.; DOTRO, G. 2013. Nitrous oxide emissions and dissolved oxygen profiling in a full-scale nitrifying activated sludge treatment plant, Water Research, 47, 524534.

AHN, J. O.; KIM, S.; PARK, H.; RAHM, B.; PAGILLA, K.; CHANDRAN, K. 2010. $\mathrm{N}_{2} \mathrm{O}$ emissions from activated sludge processes, 2008-2009: results of a national monitoring survey in the United States, Environmental Science \& Technology, 44, 4505-4511.

BROTTO, A. C.; KLIGERMAN, D. C.; PICCOLI, A. S.; DE MELLO, W. Z. 2010. Emissão de óxido nitroso de estação de tratamento de esgoto de lodos ativados por aeração prolongada - estudo preliminar, Química Nova, 33, 618-623.

BROTTO, A. C. 2011. Fatores de controle das emissões de óxido nitroso $\left(\mathrm{N}_{2} \mathrm{O}\right)$ em tanque de aeração de estação de tratamento de esgoto. Dissertação de Mestrado, Universidade Federal Fluminense.

BURGESS, J. E.; STUETZ, R. M.; MORTON, S.; STEPHENSON, T. 2002. Dinitrogen oxide detection for process failure early warning systems, Water Science and Technology, 45, 247-254.

BUTLER, M. D.; WANG, Y. Y.; CARTMELL, E.; STEPHENSON, T. 2009. Nitrous oxide emissions for early warning of biological nitrification failure in activated sludge, Water Research, 43, 1265-1272.

CRUTZEN, P. J. 1979. The role of NO and $\mathrm{NO}_{2}$ in the chemistry of the troposphere and stratosphere, Annual Review of Earth and Planetary Sciences, 7, 443-472.
CZEPIEL, P.; CRILL, P.; HARRISS, R. 1995. Nitrous oxide emissions from municipal wastewater treatment, Environmental Science \& Technology, 29, 2352-2356.

DAELMAN, M. R. J.; DE BAETS, B.; VAN LOOSDRECHT, M. C.; VOLCKE, E. I. 2013. Influence of sampling strategies on the estimated nitrous oxide emission from wastewater treatment plants, Water Research, 47, 3120-3130.

DE MELLO, W. Z.; KLIGERMAN, D. C.; PICOLLI, A. S.; RIBEIRO, R. P.; OLIVEIRA, J. L. M.; BROTTO, A. C. 2013. Nitrous oxide emissions from an intermittent aeration activated sludge system of an urban wastewater treatment plant, Química Nova, 36, p. 16-20.

EATON, A. D.; CLESCERI, L. S.; GREENBERG, A. E. 2012. Standard Methods for the Examination of Water and Wastewater, 22 ed., American Public Health Association: Washington.

FOLEY, J.; DE HASS, D.; YUAN, Z.; LANT, P. 2010. Nitrous oxide generation in full-scale biological nutrient removal wastewater treatment plants, Water Research, 44, 831-844.

HU, Z.; ZHANG. J.; XIE, H.; LIANG, S.; LI, S.; J. 2013. Minimization of nitrous oxide emission from anoxic-oxic biological nitrogen removal process: effect of influent $\mathrm{COD} / \mathrm{NH}_{4}{ }^{+}$ratio and feeding strategy, Journal of Bioscience and Bioengineering, 115, 272-278.

Intergovernmental Panel on Climate Change (IPCC). 2006. IPCC Guidelines for National Greenhouse Gas Inventories, v. 5, Kanagawa.

Intergovernmental Panel on Climate Change (IPCC). 2007. The Physical Science Basis - Contribution of Working Group I to the Fourth Assessment Report of the Intergovernmental Panel on Climate Change, Cambridge. 
KAMPSCHREUR, M. J.; TEMMINK, H.; KLEEREBEZEM, R.; JETTEN, M. S. M.; VAN LOOSDRECHT, M. C. M. 2009. Nitrous oxide emission during wastewater treatment, Water Research, 43, 4093-4103.

KIM, S-W.; MIYAHARA, M.; FUSHINOBU, S.; WAKAGI, T.; SHOUN, H. 2010. Nitrous oxide emission from nitrifying activated sludge dependent on denitrification by ammoniaoxidizing bacteria, Bioresource Technology, 101, 3958-3963.

LAW, Y.; YE, L.; PAN, Y.; YUAN, Z. 2012a. Nitrous oxide emissions from wastewater treatment processes, Philosophical Transactions of the Royal Society B, 367, 1265-1277.

LAW, Y.; NI, B.J.; LANT, P., YUAN, Z. 2012b. $\mathrm{N}_{2} \mathrm{O}$ production rate of an enriched ammonia oxidising bacteria culture exponentially correlates to its ammonia oxidation rate, Water Research, 46, 3409-3419.

LOTITO, A. M.; WUNDERLIN, P.; JOSS, A.; KIPF, M.; SIEGRIST, H. 2012. Nitrous oxide emissions from the oxidation tank of a pilot activated sludge plant, Water Research, 46, 3563-3573.

RASSAMEE, V.; SATTAYATEWA, C.; PAGILLA, K.; CHANDRAN, K. 2011 Effect of oxic and anoxic conditions on nitrous oxide emissions from nitrification and denitrification processes, Biotechnology and Bioengineering, 108, 2036-2045.

RAVISHANKARA, A. R.; DANIEL, J. S.; PORTMAN, R. W. 2009. Nitrous oxide $\left(\mathrm{N}_{2} \mathrm{O}\right)$ : the dominant ozonedepleting substance emitted in the $21^{\text {st }}$ century, Science, 326, 123-125.

RIBEIRO, R. P.; DE MELLO, W. Z.; KLIGERMAN, D. C.; OLIVEIRA, J. L. M.; ALVIM, R. B.; ANDRADE, S. A.;
BROTTO, A. C.; DE ALMEIDA, P. A. 2013. Emissões de óxido nitroso do tanque de aeração de uma estação de tratamento de esgotos com sistema de lodos ativados convencional, Química Nova, 36, 998-1003.

SIVRET, E. C.; PEIRSON, W. L.; STUETZ, R. M. 2008. Nitrous oxide monitoring for nitrifying activated sludge aeration control: a simulation study, Biotechnology and Bioengineering, 101, 109-118.

SURAMPALLI, R. Y.; TYAGI, R. D.; SCHEIBLE, O. K.; Heidman, J. A. 1997. Nitrification, denitrification and phosphorus removal in sequential batch reactors, Biotechnology and Bioengineering, 61, 151-157.

VON SPERLING, M. 2002. Lodos ativados, vol. 4, Princípios do Tratamento Biológico de Águas Residuárias, 2 ed., Departamento de Engenharia Sanitária e Ambiental da Universidade Federal de Minas Gerais: Belo Horizonte.

VON SPERLING, M. 2005. Introdução a Qualidade das Águas e ao Tratamento de Esgoto, vol. 1, Princípios do Tratamento Biológico de Águas Residuárias, 3 ed., Departamento de Engenharia Sanitária e Ambiental da Universidade Federal de Minas Gerais: Belo Horizonte.

WRAGE, N.; VELTHOF, G. L.; VAN BEUSICHEM, $M$.L.; OENEMA, O. 2001. Role of nitrifier denitrification in the production of nitrous oxide, Soil Biology \& Biochemistry, 33, 1723-1732.

WUNDERLIN, P.; MOHN, J.; JOSS, A.; EMMENEGGER, L.; SIEGRIST, $\mathrm{H}$. 2012. Mechanisms of $\mathrm{N}_{2} \mathrm{O}$ production in biological wastewater treatment under nitrifying and denitrifying conditions, Water Research, 46, 1027-1037. 